\title{
TECHNOLOGYACCEPTANCE MODEL (TAM) DALAM SURVEI BIDANG KEPENDUDUKAN DAN KELUARGA BERENCANA
}

\author{
Sukarno $^{1}$ dan Nur Laila Meilani² \\ ${ }^{1}$ Pusat Penelitian dan Pengembangan KB \& KS BKKBN Pusat \\ ${ }^{2}$ FISIP Universitas Riau, Kampus Bina Widya Km. 12,5 Simpang Baru Panam, Pekanbaru 28293
}

\begin{abstract}
Technology Acceptance Model (TAM) dalam Survei Bidang Kependudukan dan Keluarga Berencana. There are changes in techniques or data collection methods in surveys in population and family planning (hereinafter referred to as Program Performance and Accountability Surveys / SKAP) were originally done manually and paper based into smartphone-based systems using the Open Data Kit (ODK) platform ) This system transforms all series of data collection into paperless and electronic based. This study aims to (a) measure the level of influence perceived ease of use on perceived usefulness; (b) measuring the level of influence of perceived ease of use on attitude towards using: (c) measuring the level of influence of perceived usefulness on behavior intention to use; (d) measure the level of influence of perceived usefulness on attitude towards using; (e) measure the level of influence of attitude towards using on the behavior intention to use; and (f) measuring the level of influence of behavior intention to use on actual system use in surveys based on smartphones in population and family planning on the island of Sumatra. The population in this study were all SKAP survey enumerators and survey supervisors on the island of Sumatra, then the sample was determined according to the maximum likehood (ML) estimation technique that is at least 100 dna maximum of 400 respondents. Data analysis is done with SEM (Structural Equation Modeling) with AMOS (Analysis of Moment Structure) software. The results of this study show that of the six hypotheses proposed, there are two accepted hypotheses: (a) perceived ease of use has a positive relationship with Perceived usefulness with CR $-4.31> \pm$ 1.96 and the probability is $0.001(<0,05)$ and (b) behavioral Intention to Use has a positive relationship with Actual System Use with $\mathrm{CR}=2,819> \pm 1.96$ and probability / $\mathrm{P}=0.005(<0.05)$.
\end{abstract}

\begin{abstract}
Abstrak: Technology Acceptance Model (TAM) dalam Survei Bidang Kependudukan dan Keluarga Berencana. Terjadi perubahan dalam teknik atau cara pengumpulan data dalam survei di bidang kependudukan dan Keluarga Berencana/KB (selanjutnya disebut Survei Kinerja dan Akuntabilitas Program/SKAP) yang semula dilakukan secara manual dan paper based menjadi sistem yang berbasis smartphone yang menggunakan platform Open Data Kit (ODK). Sistem ini mengubah semua rangkaian pengumpulan data menjadi paperless dan electronic based. Penelitian ini bertujuan untuk (a) mengukur tingkat pengaruh perceived ease of use terhadap perceived usefulness ; (b) mengukur tingkat pengaruh perceived ease of use terhadap attitude towards using: (c) mengukur tingkat pengaruh perceived usefulness terhadap behavior intention to use; (d) mengukur tingkat pengaruh perceived usefulness terhadap attitude towards using; (e) mengukur tingkat pengaruh attitude towards using terhadap behavior intention to use; dan (f) mengukur tingkat pengaruh behavior intention to use terhadap actual system use dalam survei berbasis smartphone bidang kependudukan dan keluarga berencana di Pulau Sumatera. Populasi dalam kajian ini adalah seluruh enumerator dan supervisor survei SKAP yang ada di Pulau Sumatera, kemudian sampelnya ditetapkan menurut teknik estimasi maximum likehood (ML) yaitu minimal 100 dna maksimal 400 responden. Analisis data dilakukan dengan SEM (Structural Equation Modelling) dengan software AMOS (Analysis of Moment Structure). Hasil penelitian ini menunjukkan bahwa dari enam hipotesis yang diajukan, terdapat dua hipotesis yang diterima, yaitu (a) perceived ease of use mempunyai hubungan yang positif dengan Perceived usefulness dengan nilai CR $-4.31> \pm 1,96$ dan angka probabilitasnya $0,001(<0,05)$ dan (b) behavioral Intention to Use mempunyai hubungan yang positif dengan Actual System Use dengan $\mathrm{CR}=2,819> \pm 1,96$ dan probabilitas/ $\mathrm{P}=0,005(<0,05)$.
\end{abstract}

Kata Kunci: survei berbasis smartphone, technology acceptance model, keluarga berencana

\section{PENDAHULUAN}

Konsep reinventing government adalah karakteristik birokrasi yang mampu beradaptasi dan mampu menangkap perubahan yang berlangsung dengan sangat pesat dan cepat di masyarakat. Yang terkini, reinventing government berkembang menjadi Reinventing Government 3.0 yang tidak hanya menjadikan komputer dan internet sebagai enabler, akan tetapi lebih dari pada itu, yaitu internet of things, big data, dan 
cloud computing sebagai enabler, sehingga sering diistilahkan dengan "smart governance" (Ahmadjayadi, dkk, 2016).

Salah satu bentuk Reinventing Government 3.0 dalam birokrasi pemerintahan Indonesia adalah penyelenggaraan Survei SKAP (Survei Kinerja dan Akuntabilitas Program) yang dilakukan dengan pemanfaatan Open Data Kit (ODK) yang ter-install dalam smartphone. Penyelenggaraan survei berbasis smartphone ini merepresentasikan bahwa internet of things, big data dan cloud computing menjadi enabler dalam proses evaluasi kinerja dan juga pengambilan kebijakan bidang kependudukan dan Keluarga Berencana (KB). Secara singkat, survei ini diarahkan pada terwujudnya efektivitas serta efisiensi tata kelola BKKBN secara umum dan pengumpulan data bidang kependudukan dan KB pada khususnya, sehingga capaian kinerja BKKBN dapat terukur secara objektif dan sistematis.

Penerapan sistem Survei SKAP berbasis smartphone menjadi suatu inovasi dan terobosan baru dalam rangka pengumpulan data untuk mengukur kinerja BKKBN dalam penyelenggaraan layanan KB di Indonesia. Mekanisme survei yang selama ini dilakukan secara manual dan konvensional serta paperbased, kini diselenggarakan secara paperless dengan menggunakan aplikasi survei yang ada dalam smartphone. Pengumpulan data dalam survei merupakan garda terdepan ketika hendak mengevaluasi kinerja instansi pemerintah ataupun merumuskan intervensi kebijakan/ program/kegiatan yang kontekstual serta solutif di masing-masing bidang pembangunan, tidak terkecuali bidang kependudukan dan KB.

Salahsatu cara/alat untuk mengetahui sejauh mana penerimaan user dalam penerapan sebuah teknologi baru adalah dengan menggunakan Technology Acceptance Model (TAM). Venkatesh \& Davis (2000) menyatakan bahwa sejauh ini TAM merupakan sebuah konsep yang dianggap paling baik dalam menjelaskan perilaku user terhadap sistem teknologi informasi baru. Penelitian ini bertujuan untuk a) mengukur tingkat pengaruh perceived ease of use terhadap perceived usefulness ; (b) mengukur tingkat pengaruh perceived ease of use terhadap attitude towards using: (c) mengukur tingkat pengaruh perceived usefulness terhadap behavior intention to use; (d) mengukur tingkat pengaruh perceived usefulness terhadap attitude towards using; (e) mengukur tingkat pengaruh attitude towards using terhadap behavior intention to use; dan (f) mengukur tingkat pengaruh behavior intention to use terhadap actual system use dalam survei berbasis smartphone bidang kependudukan dan keluarga berencana di Pulau Sumatera.

\section{METODE}

Penelitian ini merupakan penelitian kuantitatif dengan populasi adalah seluruh tenaga pengumpul data (supervisor dan enumerator) dalam survei SKAP Pulau Sumatera yang berbasis smartphone. Terhadap seluruh populasi ini diberikan kuesioner yang dapat diisi melalui aplikasi Open Data Kit (ODK). Kuesioner yang telah terisi selanjutnya akan dikirimkan melalui server. Partisipasi populasi bersifat sukarela dan tanpa paksaan. Artinya, peneliti belum dapat menetapkan berapa jumlah sampel. Akan tetapi batas minimal yang dipersyaratkan untuk dapat dilakukan analisis SEM adalah sebanyak 100 responden, sehingga jika jumlah kuesioner yang telah diisi dan dikirim ke server sudah mencapai angka 100 responden, maka peneliti sudah bisa melakukan olah data.

Instrumen penelitian ini berupa kuesioner yang diadopsi dari penelitian terdahulu. Kuesioner dalam penelitian ini terdiri dari dua bagian, yaitu bagian I berupa pertanyaan terbuka yaitu pertanyaan-pertanyaan mengenai identitas responden seperti nama responden, usia dan pendidikan terakhir, sedangkan bagian II adalah pertanyaan-pertanyaan tertutup meliputi semua variabel penelitian. Uji validitas dan reliabilitas dilakukan dengan menggunakan metode Confimatory Factor Analysis yang dilakukan dengan menggunakan AMOS. Pengukuran masing-masing variabel menggunakan skala Likert mulai dari 1 sampai dengan 5 .

Analisis data dilakukan dengan analisis 
deskriptif dan analisis statistik inferensial. Analisis inferensial dilakukan dalam rangka menguji hipotesis penelitian yang telah ditetapkan sebelumnya. Pengujian hipotesis dalam penelitian ini dilakukan dengan SEM (Structural Equation Modelling) dengan software AMOS (Analysis of Moment Structure). Adapun hipotesis yang diajukan dalam penelitian ini adalah

a. H1a: Perceived ease of use mempunyai hubungan yang positif dengan Perceived usefulness dalam penggunaan sistem survei berbasis smartphone bidang kependudukan dan KB di Pulau Sumatera.

b. H1b : Perceived ease of use mempunyai hubungan yang positif dengan attitude dalam penggunaan sistem survei berbasis smartphone bidang kependudukan dan KB di Pulau Sumatera.

c. H2a : Perceived usefulness mempunyai hubungan yang positif dengan attitude towards using dalam penggunaan sistem survei berbasis smartphone bidang kependudukan dan KB di Pulau Sumatera.

d. H2b : Perceived usefulness mempunyai hubungan yang positif dengan Behavioral Intention to use sistem survei berbasis smartphone bidang kependudukan dan KB di Pulau Sumatera.

e. H3 : Attitude Toward Using mempunyai hubunganyang positif dengan behaviour intention to use sistem survei berbasis smartphone bidang kependudukan dan KB di Pulau Sumatera.

f. H4 : Behavioral intention to use mempunyai hubungan yang positif dengan Actual system use sistem survei berbasis smartphone bidang kependudukan dan KB di Pulau Sumatera.

Berdasarkan hasil analisis persamaan struktural AMOS akan diperoleh Critical Ratio (CR) dan koefisien path sehingga dapat diketahui hubungan dan pengaruh variabel independen terhadap variabel dependennya. Apabila nilai $\mathrm{CR}> \pm 1,96$ maka hipotesis diterima dan apabila nilai $\mathrm{CR}< \pm 1,96$ maka hipotesis ditolak.

\section{HASIL DAN PEMBAHASAN}

Analisis Structural Equation Model (SEM) secara Full Model digunakan untuk menguji model dan kekuatan hubungan dari tiap variabel yang dikembangkan dalam penelitian ini. Pengujian pada Structural Equation Model dilakukan dengan dua macam pengujian, yaitu uji kesesuaian model serta uji signifikansi kausalitas melalui uji koefisien regresi. Hasil pengujian dapat dilihat pada gambar sebagai berikut :

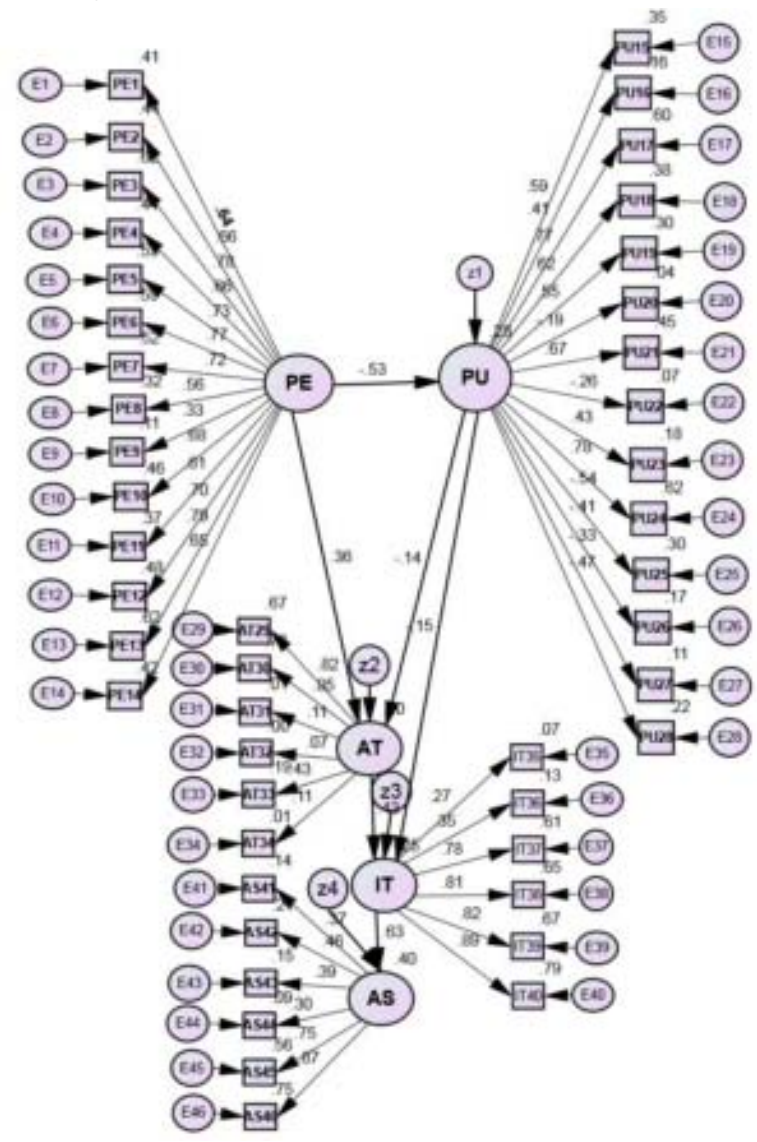

Gambar 1. Measurement Model Confimatory Factor Analysis Full Model

Gambar 1 menunjukkan hasil full analisis model yang menggambarkan hubungan antar variabel. Sebagai contoh adalah hubungan antara perceived ease of use dengan attitude toward using Hubungan antara perceived ease of use dengan attitude toward using adalah positif sebesar 0,36 yang menunjukkan bahwa semakin tinggi perceived ease of use maka semakin tinggi attitude toward using. Pada hubungan antara perceived ease of use berhubungan negatif dengan perceived of 
usefullness yang mengindikasikan bahwa semakin tinggi perceived ease of use maka semakin rendah perceived of usefullness. Hubungan antara perceived of usefullness dengan attitude toward using bersifat negatif. Kemudian perceived of usefullness berhubungan negatif dengan behavioural intension of use. Antara attitude toward using berhubungan positif dengan behavioural intension of use $(0,43)$. Sedangkan behavioural intension of use berhubungan positif dengan actual system of use $(0,63)$.

Secara umum disimpulkan bahwa Gambar 1 menunjukkan hasil pengujian SEM untuk mengetahui hasil regresi standar. Nilai koefisien regresi standar antara variabel perceived ease of use dengan variabel attitude towards using sebesar 0,36 dan nilai squared multiple correlation pada variabel yang bersangkutan adalah sebesar 0,276.

Untuk mengetahui apakah model memenuhi goodnees of fit indeks dilakukan uji kelayakan full model dengan hasil yang ditampilkan pada Tabel 1 di bawah ini. Pengujian tersebut dilakukan untuk melihat apakah model yang dikembangkan dalam penelitian ini tergolong sebagai model yang baik. Hasil evaluasi model dikatakan baik jika hasil analisis memenuhi persyaratan yang terdapat pada cut of value. Hasil evaluasi dikatakan marjinal atau cukup baik jika hasil analisis berada diantara 0,8-0,9.

Tabel 1. Hasil Pengujian Kelayakan Model Penelitian Analisis Full Model

\begin{tabular}{|l|l|r|l|}
\hline $\begin{array}{c}\text { Goodness of Fit } \\
\text { Indeks }\end{array}$ & \multicolumn{1}{c|}{ Cut of Value } & $\begin{array}{c}\text { Hasil } \\
\text { Analisis }\end{array}$ & $\begin{array}{c}\text { Evaluasi } \\
\text { Model }\end{array}$ \\
\hline Chi-Square & Diharapkan Kecil; & 1,994 & Baik \\
& $\not 2 ;$ df $: 983$ & & \\
Probability & $\geq 0,05$ & 0.000 & Marjinal \\
GFI & $\geq 0,90$ & 0.578 & Marjinal \\
AGFI & $\geq 0,90$ & 0.536 & Marjinal \\
TLI & $\geq 0,95$ & 0.624 & Marjinal \\
CFI & $\geq 0,95$ & 0.643 & Marjinal \\
CMIN/DF & $2-5$ & 2.028 & Baik \\
RMSEA & $\leq 0,08$ & 0.09 & Marjinal \\
\hline
\end{tabular}

Tabel 1 di atas menunjukkan bahwa hasil uji goodness of fit model pada kolom kedua menunjukkan nilai cut of value sedangkan pada kolom ketiga menunjukkan hasil analisis. Hasil analisis tersebut kemudian dibandingkan dengan nilai cut of value untuk menyimpulkan apakah model memenuhi goodness of fit model.

Dalam praktiknya kita sangat sulit mendapatkan model yang layak dengan memenuhi kedelapan kriteria tersebut di atas. Sebagai rule of tumb, seperti yang disampaikan oleh Agus Widarjono (2015) bila salah satu kriteria di atas sudah terpenuhi maka model sudah dianggap layak. Analisis terhadap masing-masing hasil analisis dilakukan sebagai berikut :

\section{1. $X^{2}$ Chi Square Statistics}

Pengujian Chi Square dimaksudkan untuk mengetahui perbedaan antara populasi yang diestimasi dengan sampel yang diteliti. Sehingga diharapkan tidak ada perbedaan antara sampel dan populasinya. Hal tersebut ditunjukkan dengan nilai chi square yang rendah atau nilai probabilitas yang tidak signifikan. Hasil pengujian ini menunjukkan bahwa nilai probabilitas uji sebesar 0,000 $<0,05$ yang menunjukan adanya perbedaan yang berarti antara sampel dan populasi dalam taraf nyata 5\%.

2. $C M I N / D F$

CMIN/DF atau chi square relatif merupakan hasil pembagian antara fungsi kesalahan sampel yang minimal dengan derajat kebebasannya (Ferdinand,2002). CMIN/ DF yang diharapkan agar model dapat diterima adalah 2 - 5. Nilai CMIN/DF yang dihasilkan dalam analisis ini adalah sebesar 2,028. Hasil tersebut dinilai baik karena sudah memenuhi ketentuan lebih kecil diantara 2 sampai dengan 5 .

3. GFI (Goodness of Fit Index)

Pengujian indeks ini dimaksudkan untuk mengetahui proporsi tertimbang dari varian dalam matrik kovarian sampel yang dijelaskan oleh matrik kovarian populasi terestimasi. GFI diharapkan $>0,90$. Hasil pengujian menghasilkan nilai GFI sebesar $0,578(0,578<\mathrm{GFI}<0,90)$ yang menunjukkan bahwa GFI kurang baik atau marginal. 4. AGFI (adjusted Goodnes of Fit Index) Nilai AGFI diharapkan >0,90. Hasil perhitungan menunjukkan bahwa nilai AGFI sebesar 0,536 $(0,5<\mathrm{GFI}<0,90)$ yang 
menunjukkan bahwa nilai AGFI model adalah marginal atau kurang baik atau marginal.

5. TLI (Tucker Lewis Index)

TLI adalah sebuah alternatif incremental fit index yang membandingkan sebuah model yan diuji terhadap sebuah base line model. Nilai yang diharapkan adalah TLI $>0.95$. Hasil perhitungan menunjukkan bahwa TLI sebesar 0,624 sehingga dinyatakan kurang baik.

6. RMSEA (The Root Mean Square Error of Approximation)

RMSEA merupakan indeks yang dapat digunakan untuk mengkompensasi chi square statistik dalam sampel yang besar. Uji RMSEA menunjukkan goodness of fit yang dapat diharapkan bila model diestimasi dalam populasi (Hair, dkk; 1995). Hasil RMSEA yang diharapkan agar model dapat diterima adalah $\leq 0,08$. Nilai RMSEA uji adalah sebesar 0,09 yang menunjukkan bahwa nilai RMSEA kurang baik/marjinal.

Selanjutnya dilakukan pengujian untuk melihat kekuatan hubungan dari tiap variable yang diajukan dalam penelitian ini. Hasil uji hipotesis pada kolom dependent menunjukkan variabel tergantung, variabel independent menunjukkan variable bebas, nilai estimate menunjukkan koefisien regresi dan nilai CR serta nilai $\mathrm{P}$ menunjukkan nilai kritis penerimaan dan penolakan hipotesis. Apabila nilai CR kurang dari 2 dan nilai P lebih besar dari 0.05 atau 0,01 menunjukkan bahwa hubungan kedua variabel adalah tidak signifikan secara statistik. Sebagai contoh pada hubungan yang terjadi antara variabel behaviour intension of use dengan actual system of use memiliki nilai $\mathrm{CR}=2,819$ dengan probabilitas 0,005. Hal ini berarti variabel behaviour intension of use memiliki pengaruh positif dan signifikan terhadap variabel actual system of use.

Pengujian hipotesis ini dilakukan dengan menganalisis nilai C.R dan nilai probabilitas (P) lalu dibandingkan dengan batasan statistik yang disyaratkan, yaitu diatas 1,96 untuk nilai CR dan dibawah 0,05 untuk nilai P. Apabila hasil olah data menunjukkan nilai yang meme- nuhi syarat tersebut, maka hipotesis penelitian yang diajukan dapat diterima.

Selanjutnya pembahasan mengenai pengujian hipotesis akan dilakukan secara bertahap sesuai dengan urutan hipotesis yang telah diajukan.

1. Hipotesis 1a : Perceived ease of use mempunyai hubungan yang positif dengan Perceived usefulness dalam penggunaan sistem $\mathrm{ODK}$

Penelitian ini menyatakan Perceived ease of use mempunyai hubungan yang positif dengan Perceived usefullness dalam penggunaan sistem ODK. Dari analisis Tabel 5.10 diketahui nilai CR pada pengaruh perceived ease of use terhadap perceived usefulness sebesar $-4,31$ dengan nilai $\mathrm{P}<0,05$ atau bahkan $<0,001$ ditandai dengan tanda $* * *$. Kedua nilai ini menunjukkan hasil yang memenuhi syarat, yaitu CR di bawah 1,96 dan probabilitas (P) di bawah 0,05. Dengan demikian hipotesis 1a diterima. Dengan demikian disimpulkan adanya hubungan yang berarti antara perceived usefullness dengan perceived ease of use.

Penerimaan hipotesis ini mengindikasikan bahwa peningkatan atau penurunan persepsi mengenai kemudahan sistem ODK digunakan berdampak terhadap pada peningkatan atau penurunan persepsi mengenai manfaat sistem ODK. Penerimaan hipotesis ini menguatkan rekomendasi proyek PMA2020 di Indonesia bahwa pertimbangan mengenai kemudahan penggunaan dan kemampuan sistem utilitas adalah penting, karena perceived easy of use terbukti mempengaruhi perceived usefullness dan membantu dalam proses transisi adopsi sistem baru saat diperlukan perubahan sistem.

Secara deskriptif juga diketahui bahwa persepsi responden terhadap variabel perceived usefullnes dan perceived ease of use adalah sedang, namun jawaban pada variabel tersebut cenderung 
heterogen. Heterogenitas jawaban pada kedua variabel berdampak pada penolakan dugaan bahwa perceived usefullnes berpengaruh pada perceived ease of use. Jawaban yang relatif heterogen juga mengindikasikan bahwa enumerator memiliki keyakinan yang relatif berbeda apakah ODK mudah digunakan dan bermanfaat bagi mereka dalam menyelesaikan pekerjaannya.

2. Hipotesis $1 b$ : Perceived ease of use mempunyai hubungan yang positif dengan attitude towards using dalam penggunaan sistem $O D K$

Hipotesis 1b menyatakan bahwa perceived ease of use mempunyai hubungan yang positif dengan attitude towards using dalam penggunaan sistem ODK. Berdasarkan hasil uji diketahui bahwa nilai CR pada hubungan perceived ease of use dengan attitude adalah sebesar 1,107 dengan nilai probabilitas sebesar 0,268 atau > 0,05 yang menunjukkan bahwa hipotesis $1 \mathrm{~b}$ ditolak.

3. Hipotesis 2a: Perceived usefulness mempunyai hubungan yang positif dengan attitude towards using dalam penggunaan sistem $\mathrm{ODK}$.

Hipotesis 2a penelitian ini menyatakan bahwa perceived usefullness mempunyai hubungan yang positif dengan attitude dalam penggunaan sistem ODK. Berdasarkan hasil uji hipotesis 2a diketahui bahwa nilai CR pada hubungan kedua variabel adalah sebesar $-0,869$ $(> \pm 1,96)$ dengan nilai probabilitas sebesar $0,386(>0,05)$ yang menunjukkan bahwa hipotesis 2a ditolak.

4. Hipotesis $2 b$ : Perceived usefulness mempunyai hubungan yang positif dengan Behavioral Intention to use sistem ODK.

Hipotesis 2b menyatakan bahwa Perceived usefulness mempunyai hubungan yang positif dengan Behaviour intention to use sistem ODK. Berdasarkan hasil uji model diketahui bahwa nilai CR pada hubungan antara Per- ceived usefulness dengan behaviour intention to use adalah sebesar 1,06 $(<1,96)$ dengan nilai probabilitas sebesar $0,289(>0,05)$ yang menunjukan bahwa hipotesis 2 b ditolak. Tidak adanya hubungan keduanya menunjukkan bahwa sikap enumerator terhadap sistem ODK tidak berdampak pada keinginan untuk menggunakan sistem tersebut. Hal ini mungkin berkaitan dengan adanya perubahan dari sistem paper base ke sistem ODK yang smart phone base sebagai perubahan yang memang diharuskan, sehingga keinginan untuk menggunakan atau tidak menggunakan bukan merupakan sebuah pilihan. Kalau dilihat dari sisi kegunaan memang paper base lebih terlihat sederhana karena semua pertanyaan yang ada bisa dilihat secara keseluruhan dibanding dengan smart phone.

Secara frekuensi juga diketahui bahwa secara umum enumerator suka (dimana jawaban lebih banyak mengarah ke skala setuju) terhadap sistem ODK, namun demikian tidak adanya pengaruh Perceived usefulness terhadap behavioral intention to use mengindikasikan bahwa enumerator yang memiliki perasaan suka maupun kurang suka tidak memberikan tanggapan secara serius terhadap keinginan untuk menggunakan sistem, karena pemanfatan sistem sudah merupakan pilihan yang ada.

5. Hipotesis 3 : Attitude Towards Using mempunyai hubungan yang positif dengan Behavioral Intention to use sistem ODK.

Hipotesis 3 menyatakan bahwa Attitude towards using mempunyai hubungan yang positif dengan Behaviour intention to use sistem ODK. Berdasarkan hasil uji model diketahui bahwa nilai CR pada hubungan antara Attitude Towards Using dengan behaviour intention to use adalah sebesar $-1,378$ dengan nilai P 0,168 (>0,05). Kedua nilai ini menunjukkan hasil bahwa hipotesis 3 ditolak. 
6. Hipotesis 4 : Behavioral Intention to Use mempunyai hubunganyang positif dengan Actual System Use sistem ODK.

Hipotesis 4 menyatakan bahwa Behavioral intention to use mempunyai hubungan yang positif dengan Actual system use sistem ODK. Berdasarkan hasil uji model diketahui bahwa nilai CR pada hubungan antara Behavioral intention to use dengan Actual system use adalah sebesar 2,819 dengan nilai P 0,005(< $0,05)$. Kedua nilai ini menunjukkan hasil yang memenuhi syarat, yaitu CR di atas 1,96 dan probabilitas (P) di bawah 0,05. Dengan demikian hipotesis 4 diterima. Adanya penerimaan hipotesa ini menunjukkan bahwa niat perilaku enumerator untuk menggunakan sistem ODK berdampak pada penggunaan sistem yang sebenarnya. Secara deskriptif diketahui bahwa kedua variabel masuk dalam kriteria sedang sehingga bisa disimpulkan juga bahwa perilaku enumerator yang menerima sistem yang baru ini akan meningkatkan nilai penggunaan sistem ODK. Adanya pengaruh Behavioral intention to use terhadap Actual system use mengindikasikan bahwa enumerator memiliki kecenderungan yang baik untuk selalu menggunakan sistem ini dan akan memberikan pengaruh positif terhadap penggunaan sistem yang sebenarnya.

Rangkuman menunjukkan bahwa hanya terdapat dua hipotesis yang diterima yaitu Perceived ease of use dengan Perceived usefullness (PE $<\longrightarrow \mathrm{PU})$ dan Behaviour intention to use dengan Actual System Use (IT $<\longrightarrow$ AS). Dengan diterimanya hipotesis 1a merepresentasikan bahwa persepsi kemudahan sistem ODK dalam survei berbasis smartphone berbanding lurus dengan persepsi tentang kebermanfaat sistem teknologi baru dalam survei tersebut. Artinya bahwa semakin sistem tersebut dinilai mudah untuk dioperasikan, maka akan makin dipandang bermanfaat oleh pengguna.
Berikutnya dalah penerimaan hipotesis 4 bahwa IT berhubungan dan berpengaruh positif terhadap AS. Hal ini merepresentasikan adanya kecenderungan pola perilaku users untuk memakai sistem ODK tersebut berdasarkan pengalaman nyata ketika mereka pernah memakai/mengoperasikan ODK tersebut dalam survei berbasis smartphone. Artinya bahwa seorang individu akan mau menggunakan ODK itu lagi jika sebelumnya dia pernah menggunakan/mengoperasikan ODK tersesbut dalam pekerjaannya. Pada akhirnya, penerimaan terhadap dua hipotesis ini menunjukkan bahwa secara umum teknologi baru dalam sistem berbasis smartphone dapat diterima oleh penggunanya yang ada di Pulau Sumatera.

\section{SIMPULAN}

Jumlah responden dalam penelitian ini sebanyak 129 orang yang tersebar di seluruh provinsi yang ada di Pulau Sumatera. Jumlah ini telah memenuhi teknik estimasi maximum likehood (ML) yang menjadi salahsatu syarat yang diperlukan dalam Structural Equation Model (SEM). Mayoritas responden merupakan responden perempuan (58\%), dengan dominasi usia dibawah 30 tahun (78,29\%), serta tingkat pendidikan terakhir adalah Strata 1 (53,49\%).

Pengujian hipotesis menunjukkan hasil sebagai berikut :

a. Perceived ease of use mempunyai hubungan yang positif dengan Perceived usefulness dalam penggunaan sistem ODK (hipotesis diterima) dengan nilai CR $-4.31> \pm 1,96$ dan angka probabilitasnya $0,001(<0,05)$.

$b$. Perceived ease of use tidak mempunyai hubungan yang positif dengan attitude towards using dalam penggunaan sistem ODK atau hipotesis ditolak.

c. Perceived usefulness tidak mempunyai hubungan yang positif dengan attitude towards using dalam penggunaan sistem ODK atau hipotesis ditolak. 
d. Perceived usefulness tidak mempunyai hubungan yang positif dengan Behavioral Intention to use sistem ODK atau hipotesis ditolak.

e. Attitude Towards Using tidak mempunyai hubungan yang positif dengan Behavioral Intention to use sistem ODK atau hipotesis ditolak.

f. Behavioral Intention to Use mempunyai hubungan yang positif dengan Actual System Use sistem ODK atau hipotesis diterima dengan $\mathrm{CR}=2,819$ $> \pm 1,96$ dan probabilitas $/ \mathrm{P}=0,005$ $(<0,05)$.

\section{DAFTAR PUSTAKA}

2 Billion Consumers Worldwide to Get Smart(phones) by 2016-2015. "Over half of mobile phone users globally will have smartphones in 2018", http:// www.emarketer.com/Article/2-BillionConsumers-Worldwide-Smartphonesby-2016/1011694 [diakses 5 Mei 2015].

Agus Widarjono 2015. Analisis Multivariat Terapan Dengan Program SPSS, AMOS, dan SMARTPLS. UPP STIM YKPN, Yogyakarta, 236-237.

Arief Wibowo 2006. “Kajian Tentang Perilaku Pengguna Sistem Informasi Dengan Pendekatan Technology Acceptance Model (TAM)”, http:// www.academia.edu/download/ 30907586/arif_wibowo.pdf

D. Shao, A. Loconsole and B. Hajinasabrazlighi Agarwal, R., Sambamurthy, V., \& Stair, R. 2012. "Research Report: The evolving relationship between general and specific computer self-efficacy-An empirical assessment", Information Systems Research,11(4), 418-430.

Davis, F. D., \& Arbor, A. 1989. Perceived usefulness, perceived ease of use, and user acceptance of information technology. MIS Quarterly, September.

Davis, F.D. 1986. “A technology acceptance model for empirically testing new end user information systems: theory and results”, Doctoral dissertation, Sloan School of Management, Massachusetts Institute of Technology.

DRC / Danish Refugee Council 2013. “DRC Lebanon : ODK Data Collection in the Field", http://humanitarian-nomad.org/ wp-content/uploads/2013/04/JozefLozej-DRC.pdf [accessed 06 Mei 2015) Ferdinand, Augusty. 2000. Structural Equation Modelling dalam Penelitian Manajemen. Program Magister Manajemen Universitas Diponegoro Semarang.

Jeffrey Coker, Frances et all 2010. “Open Data Kit : Implications for the Use of Smartphone Software Technology for Questionnaire Studies in International Development”, http://sel.columbia.edu/ publications.

Petra S.M. Wijaya. 2005. “Pengujian Model Penerimaan Teknologi Internet Pada Mahasiswa. Jurnal Riset Akuntansi dan Keuangan”, Vol. 1, No. 1. Februari.

Pikkarainen, et al. 2004. "Consumer acceptance of online banking: an extension of the technology acceptance model”, Internet Research Volume 14 Number 3 pp. 224-235.

Singh Harpinder 2013. "Mobile Data Collection Using an Android Device, IJCST (International Journal of Computer Science and technology )", www.ijcst. com, Vol.4, ISSue 1, Ja n - March 2013

Succi, M., and Walter, Z. 1999.”'Theory of User Acceptance of Information Technologies: An Examination of Health Care Professionals", Proceedings of the 32nd Hawaii International Conference on System Sciences (HICSS '99).

Venkatesh, V., and Davis, F. D. 2000. “A Theoretical Extension of the Technology Acceptance Model”, Four Longitudinal Field Studies, Management Science. 